\title{
Ecological Effects on Food Utilization, Trypsin Isozymes, and Performance Qualities of Growth and Maturation in Northeast Arctic Cod (Gadus morhua L.)
}

\author{
Krisna Rungruangsak-Torrissen ${ }^{1,2}$, , Karun Thongprajukaew ${ }^{2,3}$, Kanokwan Sansuwan ${ }^{3}$, \\ Passara Thapthimdaeng ${ }^{3}$, Uthaiwan Kovitvadhi ${ }^{2,3}$, Supaporn Seetaha ${ }^{4}$, \\ Kiattawee Choowongkomon ${ }^{2,4}$, Inger M. Beck ${ }^{5}$ and Ole O. Arnøy
}

${ }^{1}$ Institute of Marine Research, Ecosystem Processes Research Group, Matre Research Station, N-5984 Matredal, Norway; ${ }^{2}$ Biochemical Research Unit for Feed Utilization Assessment, ${ }^{3}$ Department of Zoology, ${ }^{4}$ Department of Biochemistry, Faculty of Science, Kasetsart University, Bangkok, Thailand; ${ }^{5}$ Institute of Marine Research, Ecosystem Processes Research Group, P.O. Box 1870 Nordnes, Bergen, Norway

\begin{abstract}
The work demonstrates, for the first time, natural biological changes in fish during maturing processes using a unique combination of different biochemical techniques. Northeast Arctic cod caught by demersal trawls were studied in three Barents Sea areas during February-March 2008. Older larger cod from area A (between North Kanin Bank and Eastern Basin) had higher food utilization efficiency (with females showing highest white muscle protein synthesis capacity) than those from areas B (Kanin Bank) and C (Central Bank). Populations in areas A and C living in separate environments showed parallel regressions of pyloric caecal slope $\mathrm{T} / \mathrm{C}$ ratio, with different elevations of trypsin specific activities and trypsin isozymes expressions. Approximately 30 trypsin isozymes were observed, with 13 isozymes of possibly exogenous trypsin isozyme fragments from prey items found at higher percentage of cod in areas A and B with higher food varieties. Larger maturing cod required higher energy from carbohydrate (probably phytoplankton), as amylase specific activity correlated with body weight. White muscle RNA levels were varied among females from different areas, but not among males. RNA and RNA/protein ratio levels were higher in oocytes than white muscle, and these levels decreased in higher developed oocytes. Oocyte trypsin-like specific activity in areas $\mathrm{B}<\mathrm{A}<\mathrm{C}$ (with oocyte $\mathrm{T} / \mathrm{C}$ ratio in areas $\mathrm{B}>\mathrm{A}>\mathrm{C}$ ) illustrated that females from area $\mathrm{B}$ (youngest with lowest oocyte protein turnover) had highest maturation rate, and would reach their spawning area(s) before those from areas A and C. Younger females (probably also males) living closer to coastal area with higher temperature and food varieties would reach sexual maturity faster than older cod and those living far from coastal area.
\end{abstract}

Keywords: Trypsin/chymotrypsin (T/C) ratio, trypsin isozymes, amylase, RNA, RNA/protein ratio, protein/lipid (P/L) ratio, pyloric caeca, white muscle, oocytes.

\section{INTRODUCTION}

Northeast Arctic cod (Gadus morhua L.) is a principal demersal predatory fish of economic importance, with its main feeding area in the Barents Sea (Fig. 1). The fish feed on a wide range of prey, including large zooplankton species, shrimp, and most available fish species especially capelin (Mallotus villosus Müller), which can represent about $30-40 \%$ of cod diet $[1,2]$. Adult cod have an annual spawning migration from the Barents Sea to the western coast of Norway, and spawning largely occurs in the Lofoten area during March-April (Fig. 1). Feeding of mature cod during this period is lower than during the rest of the year, with the main prey items being adult herring (Clupea harengus) and Norway pout (Trisopterus esmarkii) [3]. Cod larvae are advected with the Norwegian coastal current and the Norwegian Atlantic current back to the Barents Sea where they settle at the bottom around October [1]. Total

*Address correspondence to this author at the Matre Research Station, N-5984 Matredal, Norway; Tel: +47 56367539; E-mail: Krisnart@imr.no food consumption, diet composition, growth, maturation and fecundity of Northeast Arctic cod have shown large fluctuations over two decades. Differences in feeding due to trophic influences resulted in growth performance variations $[4,5]$. However, biochemical studies of food utilization (digestive efficiency) and the performance qualities of growth and maturation had never been simultaneously studied in natural ecosystems. These have been successfully studied simultaneously in aquaculture by RungruangsakTorrissen's research team using unique combinations of different biochemical techniques [6-9].

The digestive efficiency (activity ratio of trypsin to chymotrypsin, T/C ratio) related to growth $[9,10]$ and feed efficiency [6,11] have been reported in Atlantic salmon (Salmo salar L.). This could be useful for comparison of fish growth and food utilization efficiency between fish groups in different natural ecosystems where food consumption rate cannot be measured. In addition, differences in feeding could affect the qualities of white muscle and oocytes in the levels of RNA, protein and RNA/protein ratio that indicate synthesis, deposition and turnover levels of protein, 


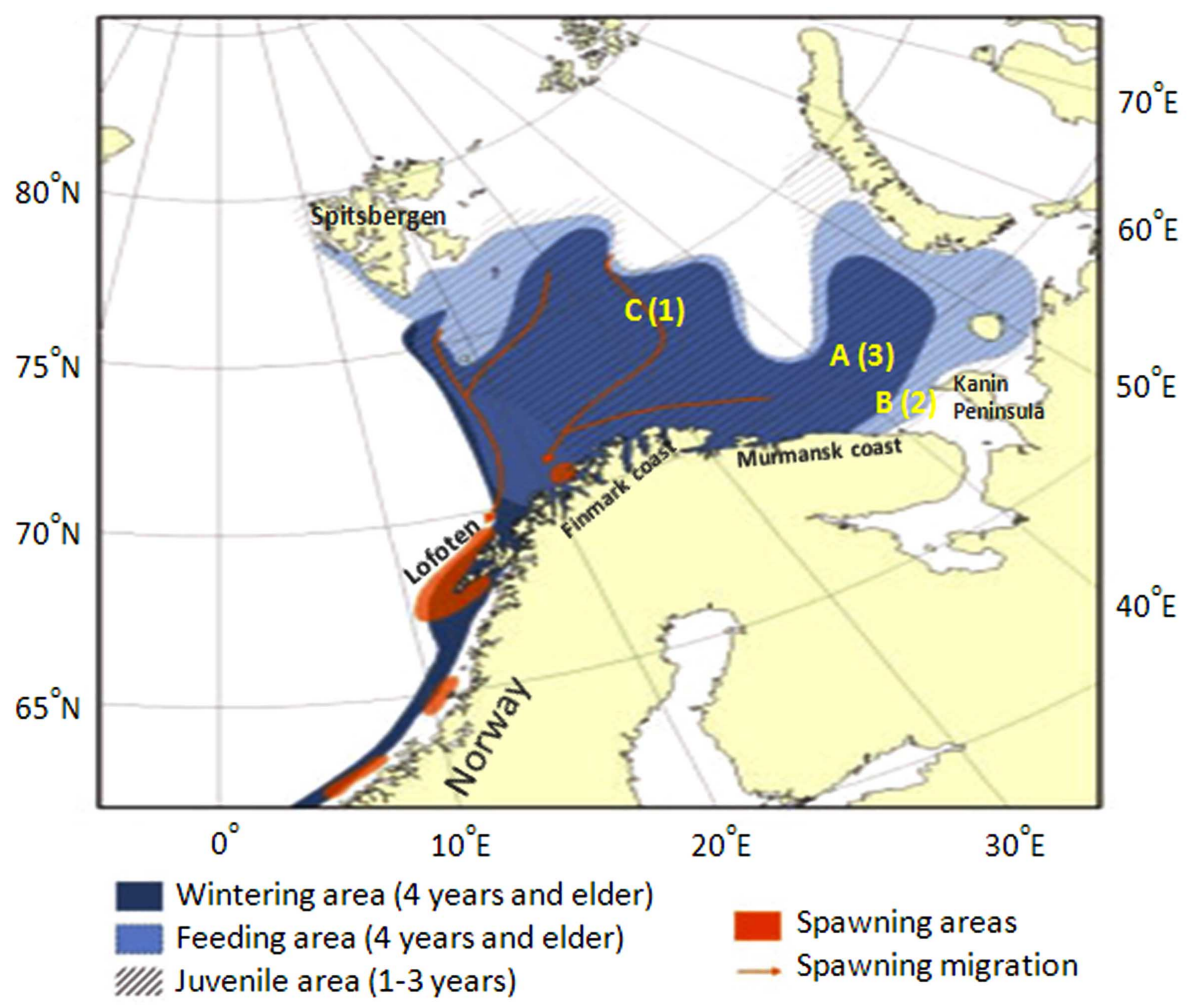

Fig. (1). Distribution areas of Northeast Arctic cod in the Barents Sea, with the three main studied areas in the present work (A, B and C) illustrated, covering six trawl stations in the area of $68-75^{\circ} \mathrm{N} 41-32^{\circ} \mathrm{E}$. The area A was between North Kanin Bank and Eastern Basin, area B was Kanin Bank, and area C was Central Bank. The number of trawl station(s) studied in each area is shown in the bracket. The areas A, B and $\mathrm{C}$ are in the regions 11,1 and 15, respectively, according to the Norwegian strata system [1]. The picture was adapted from Stiansen and Filin [1].

respectively [6, 7]. Fish living in different temperatures [12] or feeding different diets [13] during early life period possessed different trypsin phenotypes, regardless of genetic expressions of parents. Changes in environmental conditions can influence gene expressions of the fish at DNA, RNA, and protein levels, regardless of genetic expressions of parents [14]. The interaction between trypsin phenotype and feeding temperature affected the levels of trypsin specific activity and growth [10], as well as feed efficiency and growth [12]. Atlantic salmon possessing different trypsin phenotypes have different abilities to digest the same fish meals [15]. Moreover, Atlantic salmon with genetic differences in digestive abilities (trypsin phenotypes) have been shown to spatially distribute in different ambient temperatures suitable for optimum food utilization and growth in the Norwegian Sea [16].

The aim of this study was to investigate the effects of ecological variations (i.e. temperature and prey items) in different geographical areas of the Barents Sea on gene expression of trypsin isozymes, digestive efficiency and performance qualities of growth and maturation of the Northeast Arctic cod. Alternative methods (intestinal or pyloric caecal trypsin and chymotrypsin specific activities including T/C ratio, protein synthesis and turnover in white muscle and oocytes, and oocyte trypsin-like specific activity indicating oocyte maturation rate) were performed [6, 7]. This is the first investigation that the unique combination of the alternative biochemical techniques for studying trypsin gene expressions, food utilization, growth and maturation of aquatic animals are simultaneously implemented in natural ecosystems. The work could improve insight knowledge for future fisheries research and management, and environmental impact studies.

\section{MATERIALS AND METHODS}

\section{Preliminary Experiment on Oocyte Maturation}

Cod eggs at different stages were obtained from the laboratory at the Institute of Marine Research, Norway, where wild maturing Northeast Arctic cod caught by trawls during winter in the Barents Sea were acclimatized. Seven pairs were kept under natural light regime in indoor-compartments of a circular tank supplied with seawater of $10^{\circ} \mathrm{C}$. Each pair was kept separately and spawned naturally in each compartment with partitions allowing water circulation but preventing passage of buoyant eggs to other compartments. The egg samples were collected from different batches within one month during FebruaryMarch. Oocyte samples were collected using a biopsy technique $(\mathrm{n}=18)$, and mature eggs were collected before fertilization $(n=6)$ and after fertilization with more than 8 cells $(n=11)$. A batch of non-fertilized mature eggs could not be collected from one female. Each sample was divided into small portions and kept at $-80^{\circ} \mathrm{C}$ until analyses. Oocyte qualities at each stage were determined by the concentrations of RNA and protein, RNA/protein ratio, and trypsin-like specific activity. 
At ambient temperature

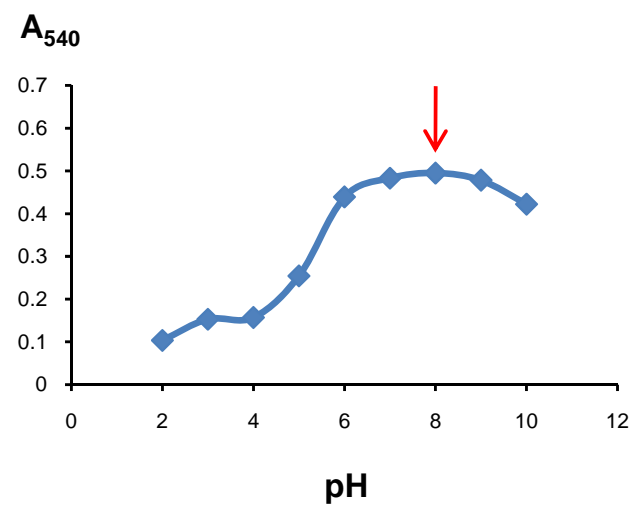

\section{At pH 8}

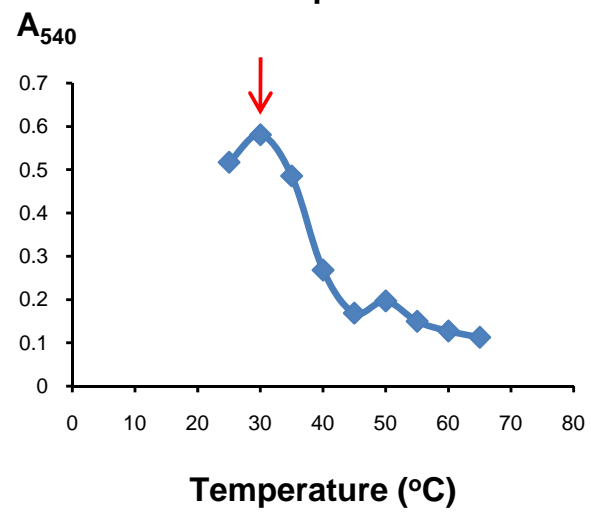

Fig. (2). Profiles of $\mathrm{pH}$ and temperature of amylase activity in the pyloric caeca of maturing Northeast Arctic cod, showing optimal pH 8 at ambient temperature and optimal temperature of $30^{\circ} \mathrm{C}$ at $\mathrm{pH} 8$. Determination was performed at 15 min enzyme reaction with absorbance measured at $540 \mathrm{~nm}$ [18].

\section{Fish Samplings and Studied Areas}

Wild Northeast Arctic cod in the Barents Sea were collected from demersal trawls during February-March 2008. Catches were performed during routine fish monitoring surveys of the Institute of Marine Research by the Norwegian research vessel Johan Hjort. The studies covered the area of $68-75^{\circ} \mathrm{N} 41-32^{\circ} \mathrm{E}$ with six trawl stations in three main areas; three stations in area A (between North Kanin Bank and Eastern Basin) during 17-18 February at 128-342 $\mathrm{m}$ depth, two stations in area B (Kanin Bank) during 18-19 February at 74-166 m depth, and one station in area $\mathrm{C}$ (Central Bank) on 5 March at 268-270 m depth. The areas A, B and C (illustrated in Fig. 1) are in the regions 11, 1 and 15 , respectively, according to the Norwegian strata system [1]. A total of 107 individuals were caught between fishing depths of 74-342 $\mathrm{m}$ with haul duration of $30 \mathrm{~min}$.

Weight and length of individual cod were measured on board. Epaxial white muscle, oocytes and pyloric caecal samples were orderly dissected to prevent contamination, and kept frozen separately at $-80^{\circ} \mathrm{C}$ until analyses. Condition factor $\left(100 \times \mathrm{W} / \mathrm{L}^{3}\right)$ was calculated from body weight $(\mathrm{W})$ and body length (L). White muscle samples were used for studying protein synthesis and turnover. Oocyte samples were used for studies of protein synthesis and turnover and maturation rate. Pyloric caecal samples were used for determinations of digestive efficiency and trypsin isozymes expressions of individual cod. The data of fish age were obtained from scale and otolith determinations.

\section{Digestive Enzymes in the Pyloric Caeca}

\section{(i). Preparation of Crude Enzyme Extracts}

Cod pyloric caecal samples with food content were extracted $(1: 3 \mathrm{w} / \mathrm{v})$ on ice in $50 \mathrm{mM}$ Tris buffer $\mathrm{pH} 8$ containing $200 \mathrm{mM} \mathrm{NaCl}$ using micro-homogenizer (THP220, OMNI International, USA). The homogenates were centrifuged at $10,000 \mathrm{~g}$ for $20 \mathrm{~min}$ at $4^{\circ} \mathrm{C}$. The supernatant of each crude enzyme extract was kept frozen at $-80^{\circ} \mathrm{C}$ until analyses of enzyme specific activities of amylase, trypsin and chymotrypsin, including expressions of trypsin isozymes. Total protein concentration of each crude enzyme extract was determined based on Lowry method [17].

\section{(ii). Determination of Amylase}

Amylase activity for carbohydrate digestion was determined by measuring the increase in reducing sugar from starch solution using 3,5-dinitrosalicylic acid (DNS) method, modified from Areekijseree et al., [18] based on Bernfeld [19], using maltose as standard. The $\mathrm{pH} 8$ and temperature of $30^{\circ} \mathrm{C}$ were chosen from a preliminary study, as the most suitable assay conditions for amylase activity in cod pyloric caeca (Fig. 2). The enzyme reaction mixture of $125 \mu \mathrm{L}$ pre-heated starch solution (1\% in $100 \mathrm{mM}$ phosphate buffer $\mathrm{pH} 8)$ and $125 \mu \mathrm{L}$ crude enzyme extract was incubated at $30^{\circ} \mathrm{C}$ for $15 \mathrm{~min}$. The reaction was stopped by adding $250 \mu \mathrm{L}$ DNS ( $1 \%$ in $2 \mathrm{M} \mathrm{NaOH}$ and $0.6 \%$ sodium potassium tartrate) and heated in boiling water for $5 \mathrm{~min}$. The mixture was then cooled down, $2.5 \mathrm{~mL}$ distilled water was added, and absorbance measured at $540 \mathrm{~nm}$. The amylase specific activity was expressed as $\mu \mathrm{mol}$ maltose produced $\mathrm{h}^{-1} \mathrm{mg}$ protein $^{-1}$.

\section{(iii). Determinations of Trypsin and Chymotrypsin}

Enzyme activities of digestive proteases, trypsin and chymotrypsin, for protein digestion were measured as described in Rungruangsak-Torrissen [6], using 1.25 M benzoyl- $L$-arginine- $p$-nitroanilide (BAPNA) and $0.1 \mathrm{M}$ $N$-succinyl-Ala-Ala-Pro-Phe- $p$-nitroanilide (SAPNA) as specific substrates, respectively, and using $p$-nitroaniline as standard. According to preliminary study, the optimum conditions chosen for assaying both trypsin and chymotrypsin activities in cod pyloric caeca were $\mathrm{pH} 8.4$ (0.2 M Tris buffer) and $45^{\circ} \mathrm{C}$ (Fig. 3). In order to be able to differentiate between cod in different studied areas, the optimum temperature has to be used instead of the habitat temperature, and the enzymes will not be destroyed during determination at the optimum temperature with short assay period (Fig. 3) as also described in Rungruangsak-Torrissen [6]. The enzyme reaction mixture of $1,000 \mu \mathrm{L}$ pre-heated substrate solution and $10 \mu \mathrm{L}$ crude enzyme extract was incubated, and absorbance of one minute initial reaction rate was measured at $410 \mathrm{~nm}$. The enzyme specific activities were expressed as $\mu \mathrm{mol} p$-nitroaniline produced $\mathrm{h}^{-1} \mathrm{mg}$ protein $^{-1}$. Digestive efficiency was expressed as the activity ratio of trypsin to chymotrypsin ( $\mathrm{T} / \mathrm{C}$ ratio). 
Pyloric caecal trypsin
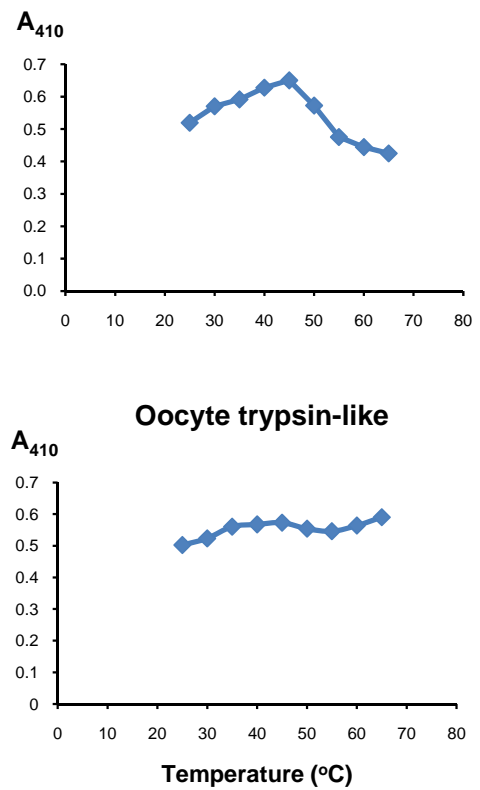

Pyloric caecal chymotrypsin
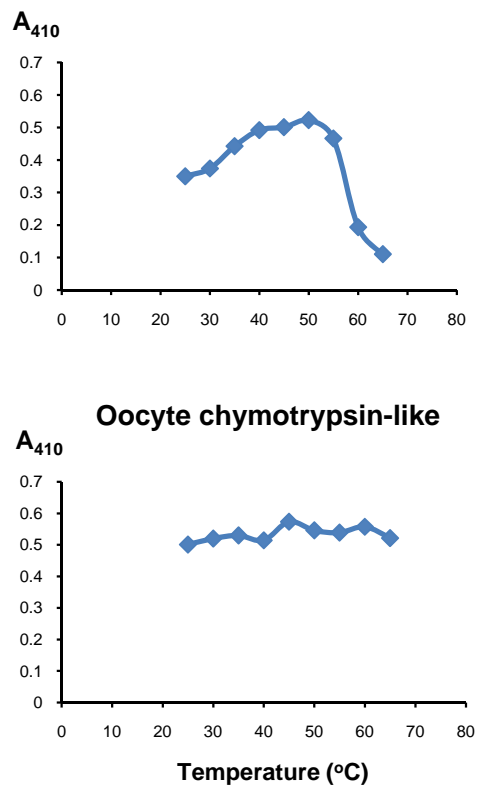

Fig. (3). Optimal temperature studies of trypsin and chymotrypsin activities in the pyloric caeca, and trypsin-like and chymotrypsin-like activities in the oocytes, of maturing Northeast Arctic cod, using 0.2 M Tris buffer pH 8.4 and determined at initial enzyme reaction rate of one minute with absorbance measured at $410 \mathrm{~nm}[6]$.

\section{Expressions of Trypsin Isozymes}

Electrophoretic zymograms of trypsin isozymes expressed in the pyloric caeca of individual cod were performed on native-polyacrylamide gel electrophoresis (native-PAGE) according to the method modified from Chong et al. [20]. The enzyme samples were prepared by mixing each crude enzyme extract at a ratio of 5:1 (v/v) with the native-PAGE sample buffer of $0.5 \mathrm{M}$ Tris- $\mathrm{HCl}$ buffer $\mathrm{pH} 6.8$ containing $20 \%$ glycerol, $0.2 \%$ bromophenol blue and $10 \%$ sodium dodecyl sulphate (SDS) (without $\beta$-mercaptoethanol and without heating to prevent destruction of enzyme activity). The mixed samples $(10 \mu \mathrm{L})$ were loaded onto the gel $(6.8 \times 9.8 \mathrm{~cm})$ made of $5 \%$ stacking gel and $15 \%$ separating gel with $10 \%$ SDS, and subjected to electrophoresis using a Mini-Protean II Cell apparatus (Atto Cooperation, Tokyo, Japan) for $60 \mathrm{~min}$ at $300 \mathrm{~mA} 65 \mathrm{~W}$ and $170 \mathrm{~V}$. In order to make the gel background opaque and the enzyme clear zones easily seen, $10 \%$ SDS was added to the running buffer ( $25 \mathrm{mM}$ Tris $\mathrm{pH} 8.3$ with $192 \mathrm{mM}$ glycine) and the gels were continued running for another $60 \mathrm{~min}$. The gel was then stained for trypsin activity by incubating at $37^{\circ} \mathrm{C}$ for $15-60 \mathrm{~min}$ (depending on the activity levels of trypsin isozymes observed) with substrate-staining solution of $N$ - $p$-tosyl- $L$-arginine methyl ester hydrochloride (TAME) at a concentration of $1 \mathrm{mg} \mathrm{mL}^{-1}$ (in $50 \mathrm{mM}$ Tris- $\mathrm{HCl}$ buffer pH 7.5 containing $1 \mathrm{mM} \mathrm{CaCl}$ ). The appearance of clear zones on the opaque gel background indicated the presence of trypsin activity.

\section{White Muscle and Oocyte Qualities}

The concentrations of RNA and protein in the white muscle and oocyte samples were determined using Trizol reagent (Life Technologies, Grand Island, NY) for a single step separation of RNA and protein, as described in Rungruangsak-Torrissen [6] modified from Sunde et al. [21].
Lipid concentration was determined as described in Rungruangsak-Torrissen et al., [8] and Supannapong et al. [22]. Protein synthesis capacity, protein turnover rate, and protein growth (protein deposition) were expressed as RNA concentration, RNA/protein ratio, and protein/lipid $(\mathrm{P} / \mathrm{L})$ ratio, respectively.

Maturation rate was determined by trypsin-like specific activities in the oocytes. Chymotrypsin-like specific activity was also measured in the oocytes. According to preliminary study (Fig. 3), the optimum conditions for assaying the activities of trypsin-like and chymotrypsin-like were the same as those for trypsin and chymotrypsin activities in the pyloric caeca, by using specific substrates BAPNA and SAPNA, respectively, with reactions performed at $\mathrm{pH} 8.4$ and $45^{\circ} \mathrm{C}$ as described above.

\section{Statistical Analyses}

The values are presented as mean \pm standard error of mean (SEM) throughout. Linear regression, analysis of variance, and $t$-test at $95 \%$ significant level were performed. Data were analyzed using Microsoft Excel (Microsoft Corporation, Redmond, WA, USA) and Statistica 5.1 software for Window ${ }^{\circledR}$ (StatSoft, Tulsa, OK, USA).

\section{RESULTS}

\section{Preliminary Experiment on Oocyte Maturation}

The levels of different biochemical parameters studied are shown in Fig. (4). RNA concentrations were significantly different $(\mathrm{P}<0.002)$ among oocytes $\left(2,945 \pm 316 \mu \mathrm{g} \mathrm{g}{ }^{-1}\right)$, non-fertilized mature eggs $\left(341 \pm 24 \mu \mathrm{g} \mathrm{g}^{-1}\right)$, and fertilized eggs $\left(756 \pm 74 \mu \mathrm{g} \mathrm{g}^{-1}\right)$, with highest levels in the oocytes. Protein concentrations were significantly higher $(\mathrm{P}<0.0001)$ in oocytes $\left(140 \pm 13 \mathrm{mg} \mathrm{g}^{-1}\right)$ than non-fertilized $(29 \pm 1 \mathrm{mg}$ $\left.\mathrm{g}^{-1}\right)$ and fertilized $\left(25 \pm 2 \mathrm{mg} \mathrm{g}^{-1}\right)$ eggs. In contrast, protein 

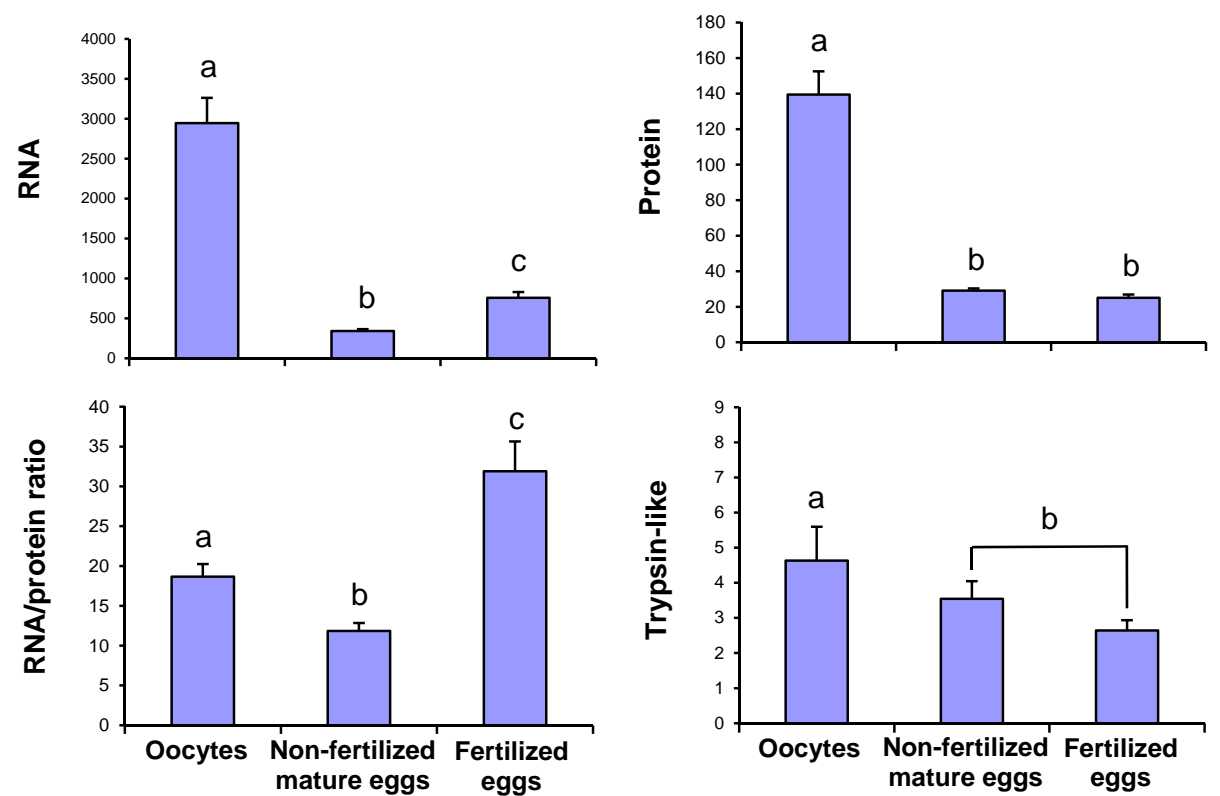

Fig. (4). Concentrations of RNA $\left(\mu \mathrm{g} \mathrm{g}^{-1}\right)$, protein $\left(\mathrm{mg} \mathrm{g}^{-1}\right)$, RNA/protein ratio $\left(\mu \mathrm{g} \mathrm{mg}^{-1}\right)$, and trypsin-like specific activity ( $\mu$ mol $p$-nitroaniline $\mathrm{h}^{-1} \mathrm{mg}$ protein ${ }^{-1}$ ) of oocytes, non-fertilized mature eggs, and fertilized eggs with more than 8 cells, from maturing Northeast Arctic cod in the preliminary experiment. The bars with different superscripts are significantly different $(\mathrm{P}<0.05)$.

turnover rate (RNA/protein ratio) were significantly different

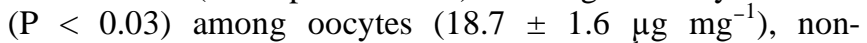
fertilized mature eggs $\left(11.8 \pm 1.0 \mu \mathrm{g} \mathrm{mg}^{-1}\right)$ and fertilized eggs $\left(31.9 \pm 3.7 \mu \mathrm{g} \mathrm{mg}^{-1}\right)$, but with highest levels in the fertilized eggs.

Similar to protein concentration, trypsin-like specific activity was significantly higher $(\mathrm{P}<0.05)$ in oocytes $(4.63$ $\pm 0.96 \mu \mathrm{mol} p$-nitroaniline $\mathrm{h}^{-1} \mathrm{mg}$ protein $^{-1}$ ) than nonfertilized and fertilized eggs $(2.80 \pm 0.29 \mu \mathrm{mol} p$-nitroaniline $\mathrm{h}^{-1} \mathrm{mg}_{\text {protein }}{ }^{-1}$, pooled data).

\section{Fish Growth}

Sizes and ages of the cod studied in the Barents Sea are shown in Table 1. In general, the cod had average sizes in the area $\mathrm{A}>$ area $\mathrm{C}>$ area $\mathrm{B}$ in accordance with their ages, regardless of sexes. The average ages of the cod in areas $\mathrm{A}$, $\mathrm{C}$ and $\mathrm{B}$ were $4.09 \pm 0.30,3.98 \pm 0.39$ and $3.23 \pm 0.15$ years, respectively. On average, cod weights were significantly higher $(\mathrm{P}<0.05)$ in area $\mathrm{A}(1.31 \pm 0.24 \mathrm{~kg})$ than area $\mathrm{B}$ $(0.64 \pm 0.22 \mathrm{~kg})$, while the cod weights in area $\mathrm{C}(0.84 \pm$ $0.11 \mathrm{~kg}$ ) were not different from those in areas A and B. Fish lengths and condition factors were similar among areas $\mathrm{A}$ $\left(44.94 \pm 3.42 \mathrm{~cm}, 0.86 \pm 0.02 \mathrm{~g} \mathrm{~cm}^{-3}\right), \mathrm{B}(35.38 \pm 4.54 \mathrm{~cm}$, $\left.0.83 \pm 0.02 \mathrm{~g} \mathrm{~cm}^{-3}\right)$ and $\mathrm{C}(43.22 \pm 1.41 \mathrm{~cm}, 0.86 \pm 0.01 \mathrm{~g}$ $\mathrm{cm}^{-3}$ ). Males seemed to be smaller and younger than females, but they were not statistically different within the same area.

\section{Digestive Enzymes in the Pyloric Caeca}

The levels of the studied digestive enzymes in cod pyloric caeca are shown in Table 1. Trypsin specific activities were significantly different $(\mathrm{P}<0.01)$ among areas A $\left(89.68 \pm 6.65 \mu \mathrm{mol} p\right.$-nitroaniline $\mathrm{h}^{-1} \mathrm{mg}$ protein $\left.{ }^{-1}\right), \mathrm{B}$ $\left(51.64 \pm 3.17 \mu \mathrm{mol} p\right.$-nitroaniline $\mathrm{h}^{-1} \mathrm{mg}$ protein $\left.{ }^{-1}\right)$ and $\mathrm{C}$ $\left(67.01 \pm 3.85 \mu\right.$ mol $p$-nitroaniline $\mathrm{h}^{-1} \mathrm{mg}$ protein $\left.{ }^{-1}\right)$, regardless of sexes. Chymotrypsin specific activities were significantly different $(\mathrm{P}<0.05)$ between areas A $(186.67 \pm$ $10.54 \mu \mathrm{mol} p$-nitroaniline $\mathrm{h}^{-1} \mathrm{mg}$ protein $\left.{ }^{-1}\right)$ and $\mathrm{B}(150.30 \pm$ 12.51 $\mu$ mol $p$-nitroaniline $\mathrm{h}^{-1} \mathrm{mg}$ protein ${ }^{-1}$ ), while those in area $C\left(172.44 \pm 6.22 \mu \mathrm{mol} p\right.$-nitroaniline $\mathrm{h}^{-1} \mathrm{mg}$ protein $\left.^{-1}\right)$ were not different from areas $\mathrm{A}$ and $\mathrm{B}$. This resulted in significantly higher $\mathrm{T} / \mathrm{C}$ ratio $(\mathrm{P}<0.05)$ in area $\mathrm{A}(0.48 \pm$ $0.02)$ than in areas $\mathrm{B}(0.37 \pm 0.05)$ and $\mathrm{C}(0.38 \pm 0.01)$. Amylase specific activities, on the other hand, were similar among areas $\mathrm{A}\left(67.21 \pm 5.12 \mu \mathrm{mol}\right.$ maltose $\left.\mathrm{h}^{-1} \mathrm{mg}_{\text {protein }}^{-1}\right)$, B $\left(89.83 \pm 12.06 \mu \mathrm{mol}\right.$ maltose $\left.\mathrm{h}^{-1} \mathrm{mg} \operatorname{protein}^{-1}\right)$ and C $\left(63.76 \pm 3.16 \mu \mathrm{mol}\right.$ maltose $\mathrm{h}^{-1} \mathrm{mg}$ protein $\left.{ }^{-1}\right)$. There were no differences in specific activities of any digestive enzymes studied between males and females within the same area.

Significant relationships between specific activities of trypsin and chymotrypsin were observed in areas A and C, with higher elevation of trypsin specific activities in area $\mathrm{A}$ than in area $\mathrm{C}$ (Fig. 5a, Table 1). The results showed similar slope $\mathrm{T} / \mathrm{C}$ ratios between area $\mathrm{A}(0.5491)$ and area $\mathrm{C}$ (0.5146), illustrating a parallel regressions of slope $\mathrm{T} / \mathrm{C}$ ratios (Fig. 5a). Significant relationship between T/C ratio and trypsin specific activity was observed in area $\mathrm{C}$, but not in area A (Fig. 5b). The relationships could not be studied in area B because of too small number of the cod samples obtained in this area.

\section{Expressions of Trypsin Isozymes}

The electrophoretic zymograms representing gene expressions of trypsin isozymes observed in the pyloric caeca with food content of maturing Northeast Arctic cod in the different studied areas in the Barents Sea are illustrated in Fig. (6). Approximately 30 trypsin isozymes were observed, and could be classified into 3 groups. The first group (numbers 1-8) was mainly expressed at lower levels than the others. The second group (numbers 9-17) and the third group (numbers 18-30) were mainly expressed at higher levels than the first group. The most common trypsin 

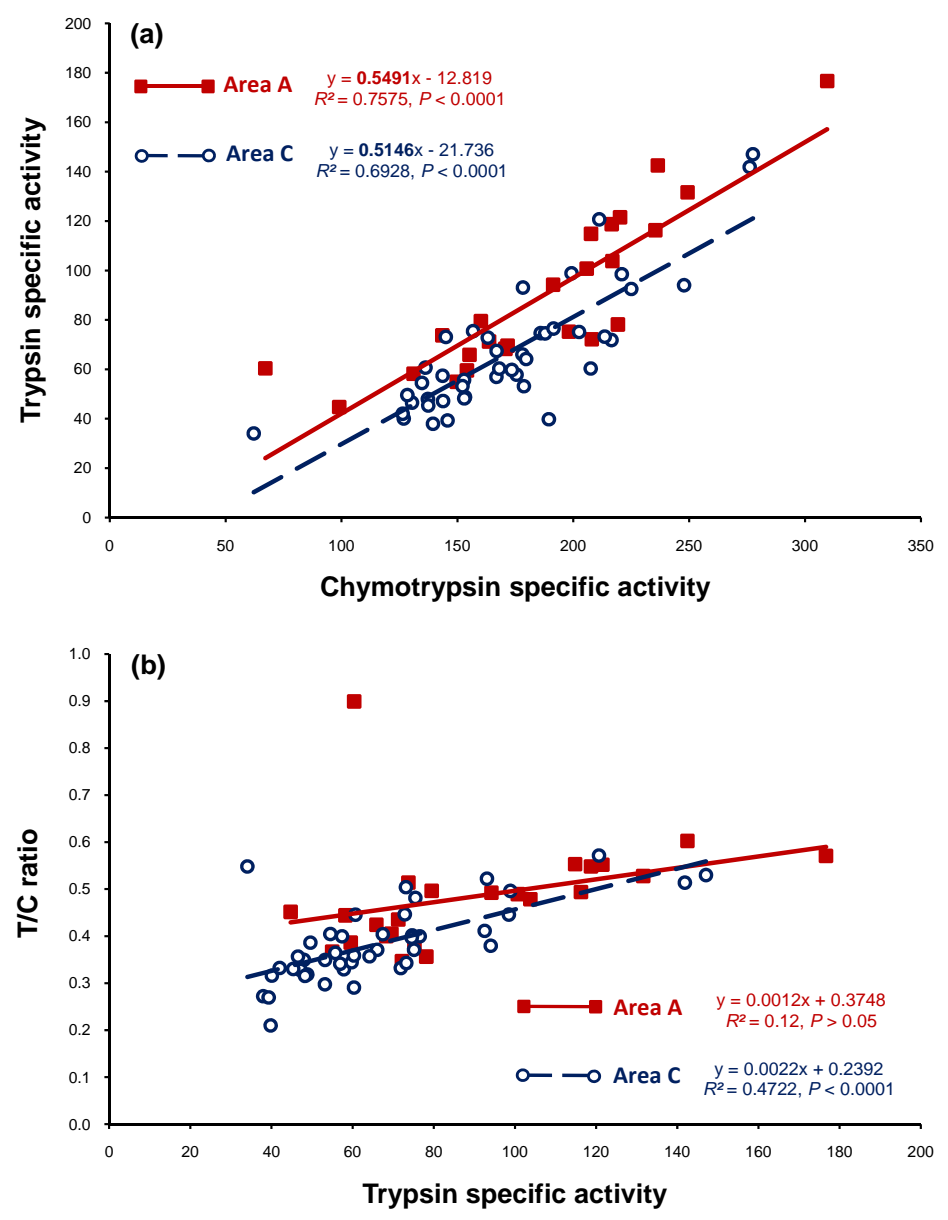

Fig. (5). Relationship studies (a) between specific activities of trypsin and chymotrypsin (expressed as $\mu \mathrm{mol} p$-nitroaniline $\mathrm{h}^{-1} \mathrm{mg} \mathrm{protein}^{-1}$ ) in the pyloric caeca showing regressions of slope T/C ratio of maturing Northeast Arctic cod in area A (0.5491) and area C (0.5146), and (b) between T/C ratio and trypsin specific activity, regardless of sexes. The area B could not be studied due to too small number of cod samples obtained in this area. The studied areas are illustrated in Fig. (1).

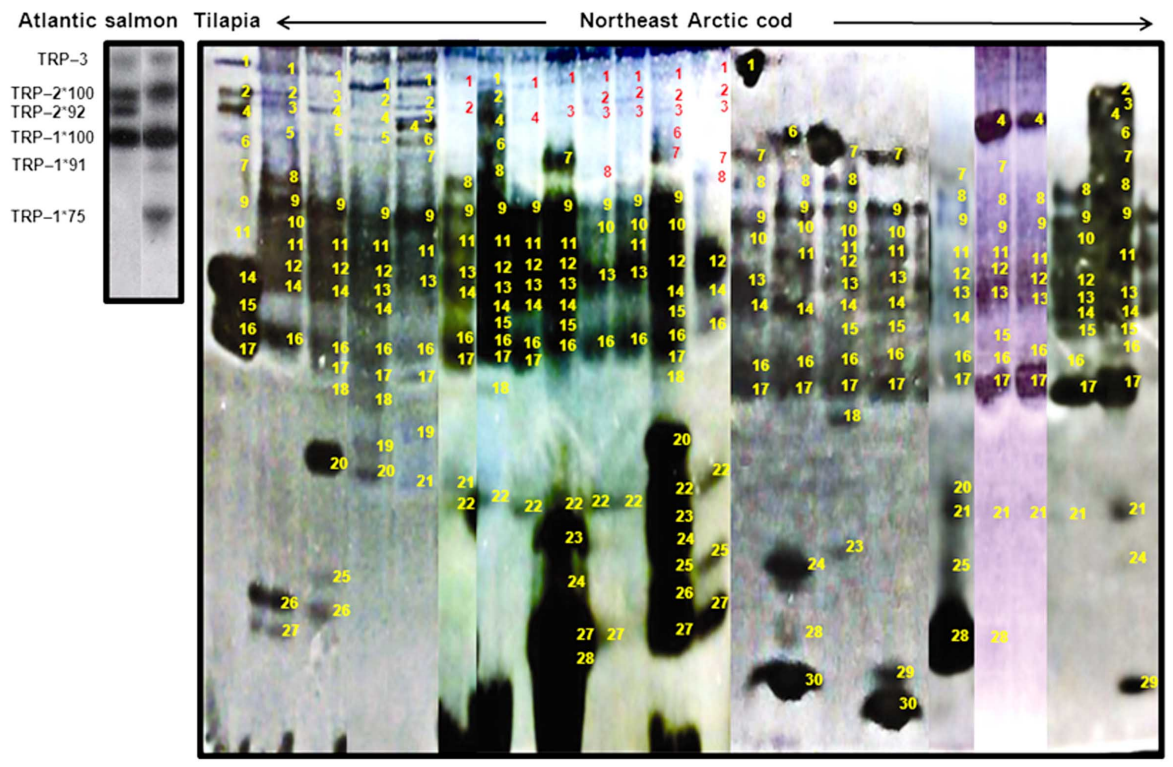

Fig. (6). Electrophoretic zymograms of trypsin isozymes on 15\% native-PAGE with TAME as substrate-staining, showing approximately 30 trypsin isozymes observed in maturing Northeast Arctic cod pyloric caecal extracts with food content in comparison with Nile tilapia intestinal extract with food content. The pictures were taken with different camera settings and with the gels on black paper to get dark enzyme activity bands. The zymograms represented trypsin isozymes of Atlantic salmon pyloric caecal tissue extracts (without food content) are also illustrated with designated names, performed by isoelectric focusing on Agarose IEF gel pH 4-6.5 with BAPNA as substrate-staining $[12,29]$. 
Table 1. Growth, Digestive Enzymes, and Qualities of White Muscle and Oocytes, of Maturing Northeast Arctic Cod in the Three Studied Areas in the Barents Sea. The Studied Areas are Illustrated in Fig. (1). Specific Activities of Trypsin, Chymotrypsin, Trypsin-Like, and Chymotrypsin-Like are Expressed as $\mu \mathrm{mol} p$-Nitroaniline $\mathrm{h}^{-1} \mathrm{mg} \mathrm{Protein}^{-1}$. Specific Activity of Amylase is Expressed as $\mu \mathrm{mol}$ Maltose $\mathrm{h}^{-1} \mathrm{mg}$ Protein $^{-1}$

\begin{tabular}{|c|c|c|c|c|c|c|}
\hline \multirow[t]{2}{*}{ Parameters } & \multicolumn{2}{|c|}{ Area A $(n=34)$} & \multicolumn{2}{|c|}{ Area $B(n=13)$} & \multicolumn{2}{|c|}{ Area $C(n=60)$} \\
\hline & $\begin{array}{l}\text { Female } \\
(n=19)\end{array}$ & $\begin{array}{c}\text { Male } \\
(n=15)\end{array}$ & $\begin{array}{c}\text { Female* }^{*} \\
(\mathbf{n}=7)\end{array}$ & $\begin{array}{c}\text { Male } \\
(n=6)\end{array}$ & $\begin{array}{l}\text { Female } \\
(n=34)\end{array}$ & $\begin{array}{c}\text { Male } \\
(n=26)\end{array}$ \\
\hline \multicolumn{7}{|l|}{ Growth } \\
\hline Weight (kg) & $1.36 \pm 0.36^{\mathrm{a}}$ & $1.24 \pm 0.32^{\mathrm{a}}$ & $0.85 \pm 0.35^{\mathrm{ab}}$ & $0.40 \pm 0.23^{\mathrm{b}}$ & $0.90 \pm 0.17^{\mathrm{ab}}$ & $0.76 \pm 0.12^{\mathrm{ab}}$ \\
\hline Length (cm) & $46.00 \pm 4.52$ & $43.60 \pm 5.39$ & $40.29 \pm 6.38$ & $29.67 \pm 6.18$ & $43.94 \pm 2.04$ & $42.27 \pm 1.87$ \\
\hline Condition Factor $\left(\mathrm{g} \mathrm{cm}^{-3}\right)$ & $0.87 \pm 0.02$ & $0.85 \pm 0.04$ & $0.85 \pm 0.03$ & $0.81 \pm 0.04$ & $0.86 \pm 0.01$ & $0.87 \pm 0.01$ \\
\hline Age (year) & $4.16 \pm 0.40$ & $4.00 \pm 0.46$ & $3.71 \pm 0.52$ & $2.67 \pm 0.56$ & $4.06 \pm 0.22$ & $3.88 \pm 0.20$ \\
\hline \multicolumn{7}{|l|}{ Digestive enzymes } \\
\hline Trypsin & $86.84 \pm 9.94^{\mathrm{a}}$ & $93.04 \pm 8.93^{\mathrm{a}}$ & $52.17 \pm 2.96^{\mathrm{b}}$ & $51.43 \pm 4.50^{\mathrm{bc}}$ & $69.45 \pm 5.63^{\mathrm{a}}$ & $63.79 \pm 5.03^{\mathrm{ac}}$ \\
\hline Chymotrypsin & $189.90 \pm 14.75$ & $182.86 \pm 15.69$ & $162.94 \pm 0.20$ & $145.24 \pm 17.51$ & $175.70 \pm 9.62$ & $168.14 \pm 7.07$ \\
\hline $\mathrm{T} / \mathrm{C}$ ratio & $0.45 \pm 0.02^{\mathrm{a}}$ & $0.52 \pm 0.04^{\mathrm{a}}$ & $0.32 \pm 0.02^{\mathrm{b}}$ & $0.39 \pm 0.08^{b}$ & $0.39 \pm 0.02^{b}$ & $0.38 \pm 0.02^{\mathrm{b}}$ \\
\hline Amylase & $67.12 \pm 7.51$ & $67.31 \pm 7.16$ & $109.58 \pm 10.88$ & $81.93 \pm 15.46$ & $65.68 \pm 4.53$ & $61.24 \pm 4.32$ \\
\hline \multicolumn{7}{|l|}{ White muscle } \\
\hline RNA $\left(\mu \mathrm{g} \mathrm{g}^{-1}\right)$ & $3,393 \pm 125^{\mathrm{a}}$ & $3,529 \pm 182^{\mathrm{a}}$ & 2,319 & $3,240 \pm 359^{a b}$ & $2,993 \pm 101^{\mathrm{b}}$ & $3,184 \pm 166^{\mathrm{ab}}$ \\
\hline Protein $\left(\mathrm{mg} \mathrm{g}^{-1}\right)$ & $364 \pm 38^{\mathrm{a}}$ & $259 \pm 28^{b}$ & 109 & $395 \pm 190^{\mathrm{ab}}$ & $349 \pm 27^{\mathrm{a}}$ & $299 \pm 22^{\mathrm{ab}}$ \\
\hline RNA/Protein $\left(\mu \mathrm{g} \mathrm{mg}^{-1}\right)$ & $11.04 \pm 1.38^{\mathrm{a}}$ & $15.41 \pm 1.62^{\mathrm{b}}$ & 21.25 & $10.09 \pm 3.95^{\mathrm{ab}}$ & $11.02 \pm 1.10^{\mathrm{a}}$ & $13.13 \pm 1.81^{\mathrm{ab}}$ \\
\hline Lipid $\left(\mathrm{mg} \mathrm{g}^{-1}\right)$ & $9.17 \pm 0.76$ & $9.14 \pm 0.66$ & 7.64 & $10.82 \pm 2.22$ & $9.82 \pm 0.46$ & $9.80 \pm 0.70$ \\
\hline Protein/Lipid & $41.83 \pm 8.56$ & $29.28 \pm 3.66$ & 14.29 & $31.28 \pm 3.28$ & $37.25 \pm 3.21$ & $33.90 \pm 3.38$ \\
\hline \multicolumn{7}{|l|}{ Oocytes } \\
\hline Trypsin-like & $16.27 \pm 1.29^{\mathrm{a}}$ & & $13.15 \pm 0.44^{\mathrm{b}}$ & & $22.80 \pm 2.24^{c}$ & \\
\hline Chymotrypsin-like & $16.99 \pm 1.12^{\mathrm{a}}$ & & $13.38 \pm 0.41^{\mathrm{b}}$ & & $25.15 \pm 2.27^{\mathrm{c}}$ & \\
\hline $\mathrm{T} / \mathrm{C}$ ratio & $0.96 \pm 0.04^{\mathrm{ab}}$ & & $0.98 \pm 0.00^{\mathrm{a}}$ & & $0.91 \pm 0.03^{\mathrm{b}}$ & \\
\hline RNA $\left(\mu g g^{-1}\right)$ & $17,501 \pm 957$ & & $18,944 \pm 116$ & & $18,766 \pm 1,098$ & \\
\hline Protein $\left(\mathrm{mg} \mathrm{g}^{-1}\right)$ & $393 \pm 46^{\mathrm{a}}$ & & $526 \pm 27^{b}$ & & $424 \pm 43^{\mathrm{a}}$ & \\
\hline RNA/Protein $\left(\mu \mathrm{g} \mathrm{mg}^{-1}\right)$ & $56.54 \pm 8.94^{\mathrm{a}}$ & & $36.11 \pm 2.05^{\mathrm{b}}$ & & $53.60 \pm 8.32^{\mathrm{a}}$ & \\
\hline Lipid $\left(\mathrm{mg} \mathrm{g}^{-1}\right)$ & $7.86 \pm 1.01$ & & $10.12 \pm 3.78$ & & $8.77 \pm 1.00$ & \\
\hline Protein/Lipid & $57.75 \pm 12.29$ & & $61.51 \pm 25.59$ & & $65.88 \pm 12.96$ & \\
\hline
\end{tabular}

* Only one female white muscle sample was obtained in area B, and statistical analysis could not be performed.

The values, in the same row, with different superscripts are significantly different $(\mathrm{P} \leq 0.05)$

isozymes with high expression observed were numbers 9,13 , 14 and 16. The 30 trypsin isozymes were found in all areas studied. The first and the second groups of high molecular weights trypsin isozymes seemed to be important for cod since they were found in most samples with variations in the levels of expression. The third group of low molecular weights was found in $45 \%$ of the samples $(62 \%$ in area A population, $57 \%$ in area B population, and $34 \%$ in area $\mathrm{C}$ population). Higher expressions of trypsin isozyme numbers 7 and 8 were observed in areas A and B, while higher expressions of trypsin isozyme numbers 4 and 17 were observed in area $\mathrm{C}$, indicating differences in characteristics of expressions of trypsin isozymes among cod from different areas in the Barents Sea.

\section{White Muscle Qualities}

The qualities of white muscle are shown in Table $\mathbf{1}$. Regardless of sexes, the levels of RNA concentration in cod white muscle were significantly higher $(\mathrm{P}<0.01)$ in area $\mathrm{A}$ $\left(3,459 \pm 108 \mu \mathrm{g} \mathrm{g}^{-1}\right)$ than area $\mathrm{C}\left(3,077 \pm 93 \mu \mathrm{g} \mathrm{g}^{-1}\right)$, while those in area $\mathrm{B}\left(2,934 \pm 371 \mu \mathrm{g} \mathrm{g}^{-1}\right)$ were not different from areas $\mathrm{A}$ and $\mathrm{C}$. Protein concentrations in white muscle were similar among cod in areas A $\left(314 \pm 26 \mathrm{mg} \mathrm{g}^{-1}\right), \mathrm{B}(300 \pm$ $\left.146 \mathrm{mg} \mathrm{g}^{-1}\right)$ and $\mathrm{C}\left(327 \pm 18 \mathrm{mg} \mathrm{g}^{-1}\right)$, resulting in similar levels of RNA/protein ratios in white muscle from cod in areas A $\left(13.14 \pm 1.12 \mu \mathrm{g} \mathrm{mg}^{-1}\right), \mathrm{B}\left(13.81 \pm 4.36 \mu \mathrm{g} \mathrm{mg}^{-1}\right)$

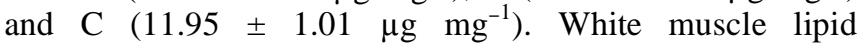
concentrations were also similar among the cod in areas A $\left(9.16 \pm 0.50 \mathrm{mg} \mathrm{g}^{-1}\right), \mathrm{B}\left(10.18 \pm 1.83 \mathrm{mg} \mathrm{g}^{-1}\right)$ and $\mathrm{C}(9.81 \pm$ 
$0.40 \mathrm{mg} \mathrm{g}^{-1}$ ), resulting in similar white muscle protein/lipid $(\mathrm{P} / \mathrm{L})$ ratios of cod in areas $\mathrm{A}(36.21 \pm 5.06), \mathrm{B}(25.62 \pm$ $5.97)$ and $C(35.77 \pm 2.32)$, regardless of sexes.

There were differences in white muscle qualities between males and females in area A where the levels of protein (259 \pm 28 vs $364 \pm 38 \mathrm{mg} \mathrm{g}^{-1}$ ) were lower and RNA/protein ratio $\left(15.41 \pm 1.62\right.$ vs $\left.11.04 \pm 1.38 \mu \mathrm{g} \mathrm{mg}^{-1}\right)$ were higher in males than in females $(\mathrm{P} \leq 0.05$, Table $\mathbf{1})$. Males and females in area $\mathrm{C}$ showed similar white muscle qualities (Table 1). Unfortunately, this could not be studied in area B because only one female white muscle sample was obtained. White muscle RNA concentrations were significantly higher in females from area $\mathrm{A}\left(3,393 \pm 125 \mu \mathrm{g} \mathrm{g}^{-1}\right)$ than area $\mathrm{C}(2,993 \pm$ $\left.101 \mu \mathrm{g} \mathrm{g}^{-1}\right)(\mathrm{P}<0.03$, Table 1). No differences were observed among males from different areas (Table $\mathbf{1}$ ).

\section{Oocyte Qualities}

The qualities of oocytes are shown in Table 1. Specific activities of trypsin-like and chymotrypsin-like in the oocytes were significantly different $(\mathrm{P}<0.05)$ among cod in all areas, with area $\mathrm{B}<$ area $\mathrm{A}<$ area $\mathrm{C}$. But this resulted in opposite $\mathrm{T} / \mathrm{C}$ ratio levels in the oocytes showing area $\mathrm{B}>$ area $\mathrm{A}>$ area $\mathrm{C}$, with significantly higher $\mathrm{T} / \mathrm{C}$ ratios in area $\mathrm{B}$ than area $\mathrm{C}(\mathrm{P}<0.03)$, while those in area $\mathrm{A}$ were not different from areas B and C. RNA concentrations in the oocytes were similar among cod in the three areas studied, while oocyte protein concentrations were significantly highest in area $\mathrm{B}$ with significantly lowest RNA/protein ratios $(\mathrm{P} \leq 0.05)$. There were no differences in the concentrations of protein and $\mathrm{RNA}$ /protein ratios in cod oocytes between area $\mathrm{A}$ and area $\mathrm{C}$. The levels of lipid and $\mathrm{P} / \mathrm{L}$ ratios in cod oocytes were similar in all areas studied.

\section{Comparisons Between Oocytes and White Muscle}

In general, the levels of RNA concentration were higher in oocytes $\left(18,188 \pm 677 \mu \mathrm{g} \mathrm{g}^{-1}\right)$ than white muscle $(3,188 \pm$ $\left.73 \mu \mathrm{g} \mathrm{g}^{-1}\right)$, regardless of studied areas $(\mathrm{P}<0.0001$, Table 1$)$. This resulted in significantly higher $\mathrm{RNA}$ /protein ratios in oocytes $\left(53.80 \pm 5.66 \mu \mathrm{g} \mathrm{mg}^{-1}\right)$ than white muscle $(12.37 \pm$ $0.76 \mu \mathrm{g} \mathrm{mg}^{-1}$ ) during maturing period $(\mathrm{P}<0.0001)$. Oocytes also showed significantly higher $\mathrm{P} / \mathrm{L}$ ratios $(61.94 \pm 8.30)$ than white muscle $(35.57 \pm 2.20)$ during maturing period $(\mathrm{P}$ $<0.02$ ), in despite of similar protein and lipid concentrations observed between oocytes $\left(417 \pm 30 \mathrm{mg} \mathrm{g}^{-1}\right.$ and $8.47 \pm 0.69$ $\mathrm{mg} \mathrm{g}^{-1}$, respectively) and white muscle $\left(322 \pm 15 \mathrm{mg} \mathrm{g}^{-1}\right.$ and $9.66 \pm 0.31 \mathrm{mg} \mathrm{g}^{-1}$, respectively).

\section{Correlation Coefficient Study}

Correlation coefficient $(r)$ between different parameters studied in Northeast Arctic cod in all three areas were investigated and shown in Table 2. It is interesting to note that fish weight during maturing period correlated with amylase specific activity. Fish length correlated negatively with protein concentration in oocytes. Condition factors (CF) correlated positively with oocyte RNA concentration, but negatively with muscle protein concentration and amylase specific activity. High correlations were observed between specific activities of trypsin and chymotrypsin in pyloric caeca, and also between specific activities of trypsin-like and chymotrypsin-like in oocytes. Muscle RNA concentration correlated with specific activities of trypsin and chymotrypsin and T/C ratio in pyloric caeca. Pyloric caecal chymotrypsin specific activity correlated with oocyte trypsin-like specific activity, and $\mathrm{T} / \mathrm{C}$ ratio in pyloric caeca and oocytes were negatively correlated. There was a negative relationship between oocyte RNA concentration and muscle lipid concentration. The level of $\mathrm{P} / \mathrm{L}$ ratio in oocytes correlated negatively with oocyte $\mathrm{T} / \mathrm{C}$ ratio, but positively with $\mathrm{T} / \mathrm{C}$ ratio in pyloric caeca.

\section{DISCUSSION}

\section{Living Conditions of Northeast Arctic Cod in the Barents Sea}

In February 2008, during sampling period, the temperatures around $100 \mathrm{~m}$ depth of the water masses in the Barents Sea were relatively high $\left(0.8-1.5^{\circ} \mathrm{C}\right)$ due to the strongly reduced inflow of Atlantic water, compared to the previous years, but the anomalies decreased throughout the year and the average temperature was only $0.5^{\circ} \mathrm{C}$ in August [23]. Considering annual means, the temperature was a little lower and the ice cover was a little higher in 2008 than in 2007. The bottom temperatures in areas A, B and C during February-March 2008 were estimated to be $1.61^{\circ} \mathrm{C}, 3.45^{\circ} \mathrm{C}$ and $1.69^{\circ} \mathrm{C}$, respectively (R. Ingvaldsen, personal communication). The levels of contaminants (radionuclides, organic contaminants, hydrocarbons, metals etc.) in sea water, sediments, and marine biota in the Barents Sea are generally low [23]. According to Gjøsæter et al. [23], the studied maturing Northeast Arctic cod caught during February-March 2008 were distributed in areas of somewhat higher temperatures with lower levels of plankton due to higher grazing, compared to the years 2006 and 2007. Performance qualities of growth and maturation of the studied cod should be depended on food availability in the previous year during autumn 2007. This explanation could be supported by the observation in maturing Atlantic salmon showing higher consumption and pyloric caecal trypsin specific activity, 5-7 months prior to maturity, which were not observed in immature Atlantic salmon [24]. Variations in diet compositions in cod stomachs were observed among different age groups and geographical areas, and they were similar between the years 2007 [25] and 2006 [26].

\section{Growth and Digestive Efficiency}

Among the three areas studied, on average, the cod in area $\mathrm{A}$ were oldest and largest with highest trypsin specific activity and $\mathrm{T} / \mathrm{C}$ ratio in the pyloric caeca, regardless of sexes (Table 1). The $\mathrm{T} / \mathrm{C}$ ratio related to feed efficiency and growth [6, 9-11], and higher trypsin specific activity indicated a higher consumption of diet [24] or dietary protein [8]. A higher dietary protein affected increased length (skeletal growth), increased protein deposition in body and white muscle, and reduced condition factor [8], which were not observed in the present study (Table 1). Therefore, in comparison with areas B and C, the cod in area A showed a higher consumption, food utilization efficiency and growth within 1-2 months period during the time of being caught, as described in Rungruangsak-Torrissen et al. [8, 9]. In addition, the cod in area $\mathrm{A}$ also showed a higher protein synthesis capacity (higher RNA concentration) in the white 


\begin{tabular}{|c|c|c|c|c|c|c|c|c|c|c|c|c|c|c|c|c|c|c|c|c|}
\hline \multirow{7}{*}{ 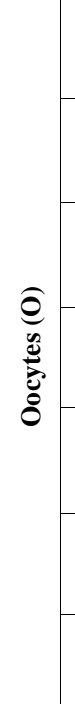 } & & & & & & & & & & & & & & & & & & & - & $\begin{array}{l}\vec{b} \\
\stackrel{0}{0}\end{array}$ \\
\hline & & & & & & & & & & & & & & & & & & - & $\begin{array}{l}\overrightarrow{0} \\
\dot{i} \\
\end{array}$ & $\begin{array}{l}\text { in } \\
\text { in } \\
1\end{array}$ \\
\hline & & & & & & & & & & & & & & & & & - & $\begin{array}{l}\hat{\infty} \\
\stackrel{i}{i} \\
1\end{array}$ & $\begin{array}{l}\infty \\
\stackrel{0}{+} \\
\stackrel{1}{*}\end{array}$ & $\stackrel{\leftrightarrow}{\leftrightarrow}$ \\
\hline & & & & & & & & & & & & & & & & - & $\begin{array}{l}2 \\
\dot{\varphi} \\
\dot{\varphi}\end{array}$ & $\stackrel{\text { ?ִ }}{8}$ & $\stackrel{m}{0}$ & $\begin{array}{l}n \\
0 \\
i\end{array}$ \\
\hline & & & & & & & & & & & & & & & - & $\stackrel{0}{0}$ & $\mid \begin{array}{c}\infty \\
\vdots \\
0\end{array}$ & ల్ల & $\begin{array}{c}\infty \\
\stackrel{m}{0} \\
0\end{array}$ & : \\
\hline & & & & & & & & & & & & & & - & $\begin{array}{l}\infty \\
\stackrel{1}{0} \\
\stackrel{1}{1}\end{array}$ & $\stackrel{n}{0}$ & $\begin{array}{l}\tilde{N} \\
\tilde{T} \\
1\end{array}$ & $\exists$ & $\begin{array}{l}\stackrel{a}{0} \\
\dot{i}\end{array}$ & $\overrightarrow{+}$ \\
\hline & & & & & & & & & & & & & - & $\stackrel{\circ}{\circ}$ & $\overrightarrow{0}$ & $\stackrel{\circ}{\circ}$ & 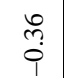 & 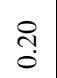 & $\vec{\Xi}$ & ָे \\
\hline \multirow{5}{*}{ 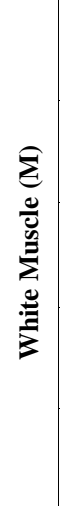 } & & & & & & & & & & & & - & $\stackrel{0}{0}$ & $\begin{array}{l}\text { oे } \\
\text { i }\end{array}$ & 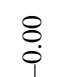 & సै & $\stackrel{0}{0}$ & $\frac{2}{0}$ & $\stackrel{1}{\dddot{0}}$ & $\stackrel{n}{0}$ \\
\hline & & & & & & & & & & & - & $\begin{array}{l}\text { ?f } \\
\stackrel{9}{0}\end{array}$ & $\stackrel{2}{0}$ & $\stackrel{\circ}{\circ}$ & $\begin{array}{l}n \\
0 \\
0\end{array}$ & $\begin{array}{l}\stackrel{9}{9} \\
\stackrel{9}{1}\end{array}$ & $\hat{n}$ & $\hat{n}$ & 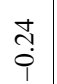 & ले \\
\hline & & & & & & & & & & - & $\underset{i}{ \pm}$ & $\begin{array}{l}\text { in } \\
\text { in } \\
1\end{array}$ & $\stackrel{0}{\circ}$ & $\stackrel{n}{0}$ & $\frac{1}{0}$ & $\stackrel{d}{\sigma}$ & $\begin{array}{l}m \\
\dot{\varphi} \\
\dot{\varphi}\end{array}$ & $\begin{array}{l}0 \\
0 \\
0\end{array}$ & त̃ & $\underset{i}{+}$ \\
\hline & & & & & & & & & - & 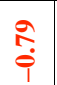 & ָֻ & $\vec{s}$ & $\begin{array}{l}n \\
\dot{i} \\
\dot{i}\end{array}$ & $\begin{array}{l}\text { to } \\
\stackrel{0}{0}\end{array}$ & $\begin{array}{l}5 \\
0 \\
0\end{array}$ & $=$ & กี & $\begin{array}{l}m \\
\stackrel{i}{i}\end{array}$ & $\begin{array}{l}\hat{\imath} \\
\hat{i}\end{array}$ & ֶָ. \\
\hline & & & & & & & & - & $\begin{array}{l}\stackrel{\leftrightarrow}{1} \\
\stackrel{i}{i}\end{array}$ & $\stackrel{\mathscr{c}}{\circ}$ & $\stackrel{0}{\circ}$ & $\stackrel{\infty}{\stackrel{\infty}{+}}$ & $\stackrel{2}{0}$ & $\stackrel{8}{8}$ & $\hat{3}$ & $\underset{T}{\stackrel{7}{0}}$ & $\begin{array}{l}0 \\
:\end{array}$ & $\begin{array}{l}0 \\
\stackrel{1}{0}\end{array}$ & $\stackrel{\circ}{0}$ & $\frac{0}{0}$ \\
\hline$\varangle$ & & & & & & & - & $\stackrel{0}{0}$ & $\stackrel{8}{\circ}$ & $\begin{array}{l}2 \\
\tilde{O} \\
\\
\end{array}$ & $\frac{n}{0}$ & $\stackrel{1}{\div}$ & $\underset{T}{ \pm}$ & $\frac{9}{9}$ & $\begin{array}{l}0 \\
0\end{array}$ & $\stackrel{n}{0}$ & $\frac{n}{0}$ & $\stackrel{ \pm}{0}$ & $\overrightarrow{\widetilde{o}}$ & $\stackrel{\infty}{\circ}$ \\
\hline$\supseteqq$ & & & & & & - & 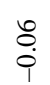 & ल) & $\stackrel{n}{0}$ & $\stackrel{0}{0}$ & $\overline{0}$ & $\stackrel{\circ}{0}$ & tr & $\begin{array}{l}\text { तิ } \\
\text { ஸे }\end{array}$ & 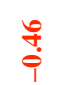 & $\begin{array}{l}\widehat{y} \\
\hat{\varphi}\end{array}$ & $\tilde{\tilde{O}}$ & 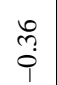 & $\begin{array}{l}0 \\
0 \\
0\end{array}$ & 守 \\
\hline U & & & & & - & 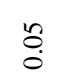 & $\begin{array}{l}0 \\
\stackrel{0}{0}\end{array}$ & $\stackrel{\leftrightarrow}{8}$ & $\overrightarrow{0}$ & $=$ & $\frac{t}{i}$ & $=$ & $\stackrel{?}{8}$ & f̊. & ô. & $\stackrel{?}{0}$ & \begin{tabular}{c}
$\vec{m}$ \\
m. \\
\multirow{1}{*}{}
\end{tabular} & तु & $\stackrel{2}{0}$ & \begin{tabular}{l}
7 \\
\multirow{0}{*}{} \\
1
\end{tabular} \\
\hline$\theta$ & & & & - & $\stackrel{\mathscr{O}}{\Theta}$ & 象 & $\stackrel{n}{0}$ & ले & $\stackrel{n}{0}$ & $\stackrel{\infty}{\stackrel{0}{0}}$ & $\underset{i}{\stackrel{2}{0}}$ & $\stackrel{ \pm}{ \pm}$ & $\underset{0}{ \pm}$ & $\stackrel{0}{0}$ & $\stackrel{\infty}{\stackrel{\varphi}{\varphi}}$ & $\begin{array}{l}\infty \\
\stackrel{0}{+} \\
\stackrel{i}{1}\end{array}$ & $\mid \begin{array}{l}\infty \\
0 \\
\dot{\varphi}\end{array}$ & $\begin{array}{l}\text { ț } \\
\dot{i}\end{array}$ & $\stackrel{1}{\circ}$ & $\stackrel{7}{\stackrel{9}{0}}$ \\
\hline ป⿻ & & & - & 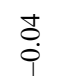 & $\stackrel{n}{0}$ & oे & $\stackrel{\text { đ̃ }}{\stackrel{1}{1}}$ & $\begin{array}{l}n \\
\stackrel{1}{0} \\
\dot{1}\end{array}$ & స్ํํ & $\frac{a}{0}$ & $\frac{a}{\dot{1}}$ & $\stackrel{l}{\circ}$ & ț & $\stackrel{0}{0}$ & $\begin{array}{l}n \\
\stackrel{2}{0} \\
\dot{1}\end{array}$ & ले & $\begin{array}{c}\tilde{N} \\
\tilde{1} \\
1\end{array}$ & ֻั & $\begin{array}{c}\infty \\
\stackrel{0}{0} \\
\end{array}$ & 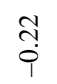 \\
\hline د & & - & $\stackrel{\infty}{\tilde{c}}$ & $\stackrel{\infty}{\circ}$ & $\frac{n}{0}$ & $\overrightarrow{0}$ & तે & $\stackrel{0}{\circ}$ & $\stackrel{m}{\stackrel{9}{0}}$ & $\begin{array}{l}0 \\
\stackrel{0}{0}\end{array}$ & $\stackrel{n}{0}$ & $\ddot{\circ}$ & $\stackrel{0}{0}$ & $\stackrel{\infty}{\stackrel{0}{0}}$ & $\stackrel{\infty}{\rightarrow+}$ & $\begin{array}{l}\stackrel{0}{0} \\
\dot{1}\end{array}$ & ले & $\stackrel{2}{0}$ & $\stackrel{\overbrace{}}{0}$ & 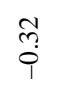 \\
\hline 3 & - & $\bar{\sigma}$ & $\widetilde{3}$ & $\stackrel{\simeq}{0}$ & $\stackrel{7}{0}$ & $\frac{t}{0}$ & $\stackrel{\widehat{~}}{0}$ & $\stackrel{0}{\circ}$ & $\stackrel{m}{\stackrel{9}{0}}$ & $\stackrel{1}{\circ}$ & $\overrightarrow{+}$ & 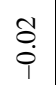 & $\stackrel{n}{0}$ & $\stackrel{0}{\circ}$ & $\begin{array}{l}\infty \\
\stackrel{1}{\uparrow} \\
\stackrel{\varphi}{1}\end{array}$ & 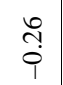 & 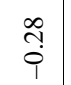 & $\stackrel{m}{0}$ & $\stackrel{0}{0}$ & $\begin{array}{l}\hat{y} \\
\hat{i}\end{array}$ \\
\hline 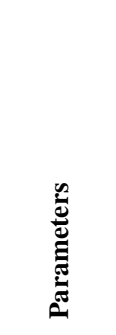 & 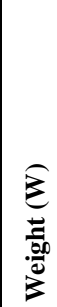 & 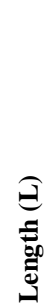 & 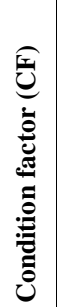 & $\begin{array}{l}E \\
\stackrel{E}{0} \\
\sum_{0}^{2}\end{array}$ & 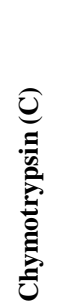 & 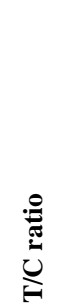 & 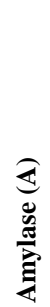 & $\frac{\overleftrightarrow{z}}{\stackrel{a}{\Delta}}$ & 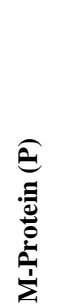 & 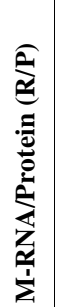 & 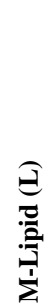 & 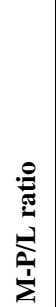 & 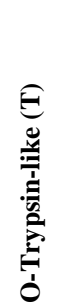 & 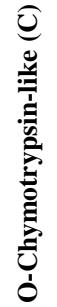 & 荀 & 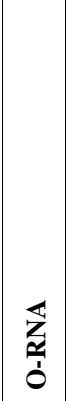 & 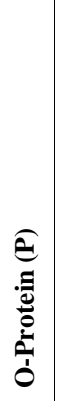 & 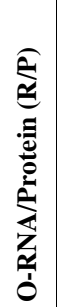 & 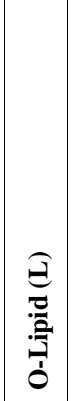 & \\
\hline
\end{tabular}


muscle than those in area $\mathrm{C}$, especially in females (Table 1). Moreover, Rungruangsak-Torrissen et al., [9] have illustrated parallel regressions of pyloric caecal slope $\mathrm{T} / \mathrm{C}$ ratio between fish living in distinct environments and crossed regressions between fish living in overlapping environments. The observed parallel regressions of similar slope $\mathrm{T} / \mathrm{C}$ ratios between the populations in areas $\mathrm{A}$ and $\mathrm{C}$ with higher elevation of trypsin specific activity in area $\mathrm{A}$ (Fig. 5a) indicated that the cod in these two areas had been living in distinct environments most of the time.

\section{Trophic Influences on Trypsin Isozymes Expressions}

The expressions of trypsin isozymes varied among Northeast Arctic cod in the different studied areas, which seemed to be influenced by the qualities and varieties of food consumption. Approximately 30 trypsin isozymes were observed in the cod pyloric caecal extracts with food content using $15 \%$ native-PAGE, and showed 11 trypsin isozymes in the first group (numbers 1, 2, 4, 6, 7) and the second group (numbers 9, 11, 14, 15, 16, 17) common to Nile tilapia (Oreochromis niloticus L.) intestinal extract with food content (Fig. 6). In Atlantic salmon, 6 trypsin isozymes (Fig. 6) with at least 10 trypsin isozyme patterns (trypsin phenotypes) have been observed in pyloric caecal tissue extracts (without food content) using isoelectric focusing on Agarose IEF gel pH 4-6.5 [12, 27-29]. Existence of cationic trypsin(s) with isoelectric point $(\mathrm{pI})>10$ was also observed [29]. In Nile tilapia, at least 6 trypsin isozymes with 10 trypsin phenotypes have been observed in the intestinal extract with food content using $12 \%$ native-PAGE, and the Nile tilapia feeding mainly on animal proteins showed differences in trypsin isozymes expressions and trypsin phenotypes from those feeding mainly on plant proteins [13, 30]. In both Atlantic salmon and Nile tilapia experiments, the fishes were fed artificial feeds. The other experiment with Atlantic salmon collected from natural ecosystems (off the Hebrides and the Norwegian Sea), about 5 trypsin isozymes were observed in the pyloric caecal tissue extracts (without food content) of post-smolts [16]. The high numbers of trypsin isozymes observed in cod in the present study could be due to natural feeding and the samples prepared from the pyloric caecal extracts with food content. Therefore, trypsin isozymes found in the third group (numbers 1830) with low molecular weights were possibly fractions of trypsin from prey items consumed by the cod. The activity of prey trypsin from the natural diet consumed (exogenous trypsin) could not be destroyed by the acidic condition in the predator stomach, as trypsin could be kept under acidic condition at low temperature without losing activity [29, 31], and exogenous trypsin could represent a very high portion of the total tryptic activity [32]. Variations in expressions of trypsin isozymes suggested an influence by different natural diets in these areas. Higher percentage of trypsin isozymes in the third group observed in cod populations from areas A $(62 \%)$ and B (57\%), compared to those from area C (34\%), indicated a higher abundance of some prey species in areas A and B. This corresponded with Anon [26] and Stiansen and Filin [25], for stomach content of cod at the ages of 3-6 years, that shrimp and capelin were the most important prey species in the central Barents Sea (area C) while shrimp, herring, krill and capelin including other unidentified foods were dominating in southeastern area (areas A and B).

\section{Effects of White Muscle and Oocyte Qualities on Maturity}

White muscle qualities did not seem to be different among males from the different studied areas, while some differences were observed among females (Table 1). During maturing process, the fish reduced somatic growth while increased oocyte development (oocyte growth), showing more than 5 times higher levels of capacity for protein synthesis (RNA concentration) and turnover (RNA/protein ratio) in oocytes than white muscle (Table $\mathbf{1}$ ), similar to previous observation [7]. Decreases in the levels of RNA, protein, RNA/protein ratio, and trypsin-like specific activity were observed in highly mature eggs (Fig. 4). After fertilization, increases in the levels of protein synthesis and turnover were observed (Fig. 4) due to cell growth. The females caught in the three areas had less developed eggs than the females in the preliminary study because of higher levels of RNA, protein, RNA/protein ratio, and trypsin-like specific activities, in the oocytes (Table 1 and Fig. 4). This means that the eggs of the females in the area A (caught during 17-18 February), area B (caught during 18-19 February) and area $\mathrm{C}$ (caught on 5 March) would have to be more developed during sexual migration to spawning areas in March-April (see Fig. 1). The levels of trypsin-like specific activity in the cod oocytes observed in area $\mathrm{B}<$ area $\mathrm{A}<$ area $C$ (Table 1) suggested that the females from area $B$ (with also the lowest oocyte RNA/protein ratio) had highest maturation rate, and would reach their spawning area(s) before the females from area A, probably in March. The females from area $\mathrm{C}$ would reach their spawning area(s) later, probably in April. No one knows exactly where they spawned. The other indication of a slower maturation rate of the cod in area $\mathrm{C}$ than in area $\mathrm{A}$ was also observed (Fig. 5b), as the cod in area $\mathrm{C}$ showed the relationship between trypsin specific activity and $\mathrm{T} / \mathrm{C}$ ratio in the pyloric caeca (indicated still having somatic growth) while those in area A showed a lower slope with lacking relationship (indicated stopping somatic growth), regardless of sexes [see 8, 10 for more information]. This suggests that the males from each studied area probably also reach their spawning area(s) at the same time as the females from the same living area. These results illustrate that younger cod living closer to coastal area would reach sexual maturity stage faster than older cod and those living far from coastal area.

It is interesting to note that the levels of $\mathrm{T} / \mathrm{C}$ ratio in the oocytes, showing area $\mathrm{B}>$ area $\mathrm{A}>$ area $\mathrm{C}$ (Table 1), indicated a higher oocyte development with higher oocyte T/C ratio despite of lower specific activity levels of trypsin-like and chymotrypsin-like. The $\mathrm{T} / \mathrm{C}$ ratio is a very important studied factor, as higher levels of $\mathrm{T} / \mathrm{C}$ ratio in the pyloric caeca [6, 9-11, present work] and oocytes [present work] indicate higher development in somatic growth and oocyte maturation rate, respectively, independent of the specific activity levels of the two proteases. More varieties of prey species and more abundance of some prey species in areas A and B could also result in higher rate of maturation of the cod, compared to area C. Moreover, temperature could influence maturation rate, as tropical species generally 
become sexually mature at younger age than temperate species. The highest maturation rate observed in the females in area B could also be resulted from the acceleration effect of the relatively high bottom temperature $\left(3.45^{\circ} \mathrm{C}\right)$, compared to areas $\mathrm{A}\left(1.61^{\circ} \mathrm{C}\right)$ and $\mathrm{C}\left(1.69^{\circ} \mathrm{C}\right)$.

\section{Mobilization of White Muscle Protein During Maturation}

Variations in diet compositions among areas $\mathrm{A}, \mathrm{B}$ and $\mathrm{C}$ had some effects on digestive efficiency, fish growth and the qualities of white muscle and oocytes (Table 1). The cod in area A with higher protein digestive efficiency had higher capacity for protein synthesis in the white muscle in both sexes, especially in females that also showed higher oocyte maturation rate, compared to those in area C. Protein mobilization from muscle to gamete is probably higher in males than in females, as lower protein levels and higher protein turnover rates in white muscle were observed in males from areas A and C (Table 1). However, a significant difference was only observed in area A, probably due to higher maturation rate than area $\mathrm{C}$. In females, the levels of $\mathrm{P} / \mathrm{L}$ ratios were higher in the oocytes than in the white muscle in spite of similar protein and lipid concentrations observed between these tissues (Table 1). This was probably due to the mobilization of protein during sexual maturation from white muscle to oocytes where proteins would be hydrolyzed by proteases (trypsin-like and chymotrypsin-like enzymes) in the oocytes into amino acids [see 7 for more information] reserved as food for offspring after hatching. The proteases, trypsin-like and chymotrypsin-like, in the oocytes are not the same as the proteases observed in the digestive tract [33, present work], as they have different characteristics under the same temperatures whereas the pyloric caecal proteases are more sensitive to higher temperatures than the oocyte proteases (Fig. 3). The levels of both protein and $\mathrm{P} / \mathrm{L}$ ratio should be studied instead of the levels of either protein or lipid alone [8, present work]. A higher oocyte protein level of the cod in area $\mathrm{B}$, compared to those in areas $\mathrm{A}$ and $\mathrm{C}$, seemed to be due to a higher protein mobilization from the white muscle, as high protein turnover and low $\mathrm{P} / \mathrm{L}$ ratio in the white muscle were observed, but it cannot be concluded due to the muscle values came from only one female (Table $\mathbf{1}$ ).

\section{Relationships Among Different Studied Parameters}

The study of relationships between different parameters illustrated that the levels of T/C ratio in the pyloric caeca showed the ability of the fish to digest dietary protein for growth and deposition in the body and white muscle where the protein would be mobilized to oocytes, and the levels of $\mathrm{T} / \mathrm{C}$ ratio in the oocytes showed the ability to hydrolyze oocyte protein during maturing process (Table 2). This supports the above explanation on protein utilization, protein mobilization and oocyte development during sexual maturation. The correlation coefficients between different parameters indicated the importance of trypsin and chymotrypsin specific activities and $\mathrm{T} / \mathrm{C}$ ratio in the pyloric caeca for protein synthesis in the white muscle, as well as of trypsin-like specific activity and $\mathrm{T} / \mathrm{C}$ ratio in the oocytes for oocyte development during maturing process (Table 2 ). The level of pyloric caecal T/C ratio (related to growth and protein deposition) was negatively correlated with the oocyte T/C ratio (Table 2), due to decreasing somatic growth during increasing oocyte development for sexual maturation [8]. It was important for the level of $\mathrm{P} / \mathrm{L}$ ratio in the oocytes (Table 2) because of muscle protein deposition level influencing oocyte protein level. The oocyte $\mathrm{T} / \mathrm{C}$ ratio was negatively correlated with oocyte $\mathrm{P} / \mathrm{L}$ ratio (Table 2 ), due to protein hydrolysis in the oocytes during sexual maturation process. The T/C ratio in the pyloric caeca did not correlate to fish growth in this study because the fish reduced somatic growth during maturation process and used most of energy for oocyte development. A relationship between maturing fish weight and amylase specific activity in the pyloric caeca (Table 2) probably indicate a higher requirement of energy from dietary carbohydrate in larger fish for maturation process, although amylase specific activity did not show any significant differences among cod in the three studied areas. A dietary carbohydrate source was probably phytoplankton that bloomed during winter period.

\section{CONCLUSIONS}

The work focuses on natural biological changes in fish during maturing processes using a unique combination of different biochemical techniques that have never been performed elsewhere. The Northeast Arctic cod (Gadus morhua L.) caught by demersal trawls were studied in three areas of the Barents Sea during February-March 2008. Older larger cod from area A (between North Kanin Bank and Eastern Basin) had higher food utilization efficiency [higher pyloric caecal trypsin specific activity and activity ratio of trypsin to chymotrypsin (T/C ratio)] with females showing highest white muscle protein synthesis capacity, compared to those from area B (Kanin Bank) and area C (Central Bank). The populations in areas $\mathrm{A}$ and $\mathrm{C}$ living in separate environments showed parallel regressions of pyloric caecal slope T/C ratio, with different elevations of trypsin specific activities and trypsin isozymes expressions. Approximately 30 trypsin isozymes were observed in cod pyloric caeca with food content, with 17 isozymes found in most samples, and 13 isozymes with low molecular weights (found in $45 \%$ of samples) of possibly exogenous trypsin isozyme fragments from prey items. Higher percentage of cod with prey trypsin isozymes fragments was observed in populations living in areas A and B with higher food varieties, compared to area C. Larger maturing cod required higher energy from dietary carbohydrate (probably phytoplankton), as amylase specific activity correlated with body weight. Variations in white muscle qualities (RNA levels) were observed among females from different studied areas, but not among males. Maturing females had higher protein synthesis (RNA concentration) and turnover (RNA/protein ratio) in oocytes than white muscle. A high oocyte trypsin-like specific activity observed indicated that the oocytes would be more developed during spawning migration, and the levels in females in areas $\mathrm{B}<\mathrm{A}$ $<\mathrm{C}$ (with oocyte T/C ratio in areas $\mathrm{B}>\mathrm{A}>\mathrm{C}$ ) illustrated that the females from area B (youngest with lowest oocyte protein turnover) had highest maturation rate and would reach their spawning area(s) before those from areas $A$ and C. The results indicated that younger females (probably also males) living closer to coastal area with higher temperature 
and food varieties would reach sexual maturity stage faster than older cod and those living far from coastal area.

In order to be able to deeply understand trophicity in natural ecosystems, the biochemical methods applied in this study have to be used for investigating the effects of environmental impacts or climate changes on biological changes in living organisms in addition to the conventional methods used in fisheries research. Future studies should be emphasized in different seasons and different years, and more areas, horizontally and vertically, for comparisons. Long term study of ecological effects on changes in the biochemical processes in living organisms will improve our knowledge on ecosystem processes.

\section{CONFLICT OF INTEREST}

None declared.

\section{ACKNOWLEDGEMENTS}

The authors are grateful to K. Michalsen (then Head of Research Group Distribution and Trophic Interactions, Institute of Marine Research, Norway) and G.O. Johansen (Head of Research Group Ecosystem Processes, Institute of Marine Research, Norway) for personal support and encouragement; my colleagues at the Institute of Marine Research, A. Thorsen and O.S. Kjesbu for providing cod eggs in the preliminary experiment, R. Ingvaldsen for providing temperature data of the studied areas, those who provided data for fish age, and the crew on the research vessel Johan Hjort for their contributions; and the Association of Thai Professionals in Europe (ATPER) for cooperation.

\section{REFERENCES}

[1] Stiansen JE, Filin AA, Eds. Joint PINRO/IMR Report on the State of the Barents Sea Ecosystem in 2007, with Expected Situation and Considerations for Management. IMR-PINRO Joint Report Series 2008(1). Bergen, Norway: Institute of Marine Research 2008.

[2] Stiansen JE, Korneev O, Titov O, Arneberg P, Eds., Filin A, Hansen JR, Høines ̊, Marasaev S, Co-eds. Joint Norwegian-Russian environmental status 2008, Report on the Barents Sea Ecosystem, Part II - Complete report. IMR-PINRO Joint Report Series 2009(3). Bergen, Norway: Institute of Marine Research 2009.

[3] Michalsen K, Johannesen E, Bogstad B. Feeding of mature cod (Gadus morhua) on the spawning grounds in Lofoten. ICES J Mar Sci 2008; 65: 571-80.

[4] Mehl S, Sunnanå K. Changes in growth of Northeast Arctic cod in relation to food consumption in 1984-1988. ICES Mar Sci Symp 1991; 193: 109-12.

[5] Yaragina NA, Marshall CT. Trophic influences on interannual and seasonal variation in the liver condition index of Northeast Arctic cod (Gadus morhua). ICES J Mar Sci 2000; 57: 42-5.

[6] Rungruangsak-Torrissen K. Digestive efficiency, growth and qualities of muscle and oocyte in Atlantic salmon (Salmo salar L.) fed on diets with krill meal as an alternative protein source. J Food Biochem 2007; 31: 509-40.

[7] Rungruangsak-Torrissen K, Fosseidengen JE. Effect of artificial feeding on digestive efficiency, growth and qualities of muscle and oocyte of maturing Atlantic mackerel (Scomber scombrus L.). J Food Biochem 2007; 31: 726-47.

[8] Rungruangsak-Torrissen K, Stien LH, Daae BS, et al. Different dietary levels of protein to lipid ratio affected digestive efficiency, skeletal growth, and muscle protein in rainbow trout families. Scholarly Research Exchange, vol. 2009, 2009, Article ID 709529, doi: $10.3814 / 2009 / 709529$.
[9] Rungruangsak-Torrissen K, Sunde J, Berg AE, Nordgarden U, Fjelldal PG, Oppedal F. Digestive efficiency, free amino acid pools and quality of growth performance in Atlantic salmon (Salmo salar L.) affected by light regimes and vaccine types. Fish Physiol Biochem 2009; 35: 255-72.

[10] Rungruangsak-Torrissen K, Moss R, Andresen LH, Berg A, Waagbø R. Different expressions of trypsin and chymotrypsin in relation to growth in Atlantic salmon (Salmo salar L.). Fish Physiol Biochem 2006; 32: 7-23

[11] Sunde J, Eiane SA, Rustad A, et al. Effect of fish feed processing conditions on digestive protease activities, free amino acid pools, feed conversion efficiency and growth in Atlantic salmon (Salmo salar L.). Aquacult Nutr 2004; 10: 261-77.

[12] Rungruangsak-Torrissen K, Pringle GM, Moss R, Houlihan DF. Effects of varying rearing temperatures on expression of different trypsin isozymes, feed conversion efficiency and growth in Atlantic salmon (Salmo salar L.). Fish Physiol Biochem 1998; 19: 247-55.

[13] Rungruangsak-Torrissen K, Engkagul A, Aeidnoie Y, et al. Development of suitable feed for commercial production of Nile tilapia, Oreochromis niloticus. Kasetsart University Technical Report 2010. Biochemical Research Unit for Feed Utilization Assessment. Bangkok, Thailand: Kasetsart University 2010.

[14] Rungruangsak-Torrissen K. Wild salmon should not be threatened by healthy and non-genetically manipulated escapees. ICES CM 2002 Documents and ICES Annual Report for 2002. Copenhagen, Denmark: ICES Conference, CM 2002/T:07. 1-5 October 2002.

[15] Bassompierre M, Ostenfeld TH, McLean E, Rungruangsak Torrissen K. In vitro protein digestion, and growth of Atlantic salmon with different trypsin isozymes. Aquacult Int 1998; 6: 47-56.

[16] Rungruangsak-Torrissen K, Stensholt BK. Spatial distribution of Atlantic salmon post-smolts: Association between genetic differences in trypsin isozymes and environmental variables. In: Kruse GH, Bez N, Booth A, Dorn MW, Hills S, Lipcius RN, Pelletier D, Roy C, Smith SJ, Witherell D, Eds. Spatial processes and management of marine populations. Fairbanks, USA: University of Alaska Sea Grant 2001; pp. 415-29.

[17] Lowry OH, Rosenbrough NJ, Farr AL, Randall RJ. Protein measurement with Folin phenol reagent. J Biol Chem 1951; 193: 265-75.

[18] Areekijseree M, Engkagul A, Kovitvadhi U, et al. Temperature and $\mathrm{pH}$ characteristics of amylase and proteinase of adult freshwater pearl mussel, Hyriopsis (Hyriopsis) bialatus Simpson 1900. Aquaculture 2004; 234: 575-87.

[19] Bernfeld P. Enzymes of starch degradation and synthesis. Adv Enzymol Rel Subj Biochem 1951; 12: 379-28.

[20] Chong ASC, Hashim R, Chow-Yang L, Ali AB. Partial characterization and activities of proteases from the digestive tract of discus fish (Symphysodon aequifasciata). Aquaculture 2002; 203: 321-33.

[21] Sunde J, Taranger GL, Rungruangsak-Torrissen K. Digestive protease activities and free amino acids in white muscle as indicators for feed conversion efficiency and growth rate in Atlantic salmon (Salmo salar L.). Fish Physiol Biochem 2001; 25: 335-45.

[22] Supannapong P, Pimsalee T, A-komol T, Engkakul A, Kovitvadhi U, Kovitvadhi S, Rungruangsak-Torrissen K. Digestive enzymes and in-vitro digestibility of different species of phytoplankton for culture of the freshwater pearl mussel, Hyriopsis (Hyriopsis) bialatus. Aquacult Int 2008; 16: 437-53.

[23] Gjøsæter H, Dommasnes A, Falkenhaug T, Hauge M, Johannesen E, Olsen E, Skagseth Ø, Eds. Havets ressurser og miljø 2009. Bergen, Norway: Institute of Marine Research, 2009.

[24] Torrissen KR, Torrissen OJ. Protease activities and carotenoid levels during the sexual maturation of Atlantic salmon (Salmo salar). Aquaculture 1985; 50: 113-22.

[25] Stiansen JE, Filin AA, Eds. Survey report from the joint Norwegian/Russian ecosystem survey in the Barents Sea. AugustSeptember 2007. IMR-PINRO Joint Report Series 2008(2). Bergen, Norway: Institute of Marine Research 2008.

[26] Anon. Survey report from the joint Norwegian/Russian ecosystem survey in the Barents Sea. August-October 2006 (Vol.2). IMR-PINRO Joint Report Series 2007(1): Bergen, Norway: Institute of Marine Research 2007. 
[27] Torrissen KR. Characterization of proteases in the digestive tract of Atlantic salmon (Salmo salar) in comparison with rainbow trout (Salmo gairdneri). Comp Biochem Physiol 1984; 77B: 669-74.

[28] Torrissen KR. Genetic variation in growth rate of Atlantic salmon with different trypsin-like isozyme patterns. Aquaculture 1991; 93 : 299-12.

[29] Rungruangsak Torrissen K, Male R. Trypsin isozymes: development, digestion and structure. In: Haard NF, Simpson BK, Eds. Seafood Enzymes, utilization and influence on postharvest seafood quality. New York: Marcel Dekker Inc. 2000; pp. 215-69.

[30] Rungruangsak-Torrissen K. Trypsin and its implementations for growth, maturation, and dietary quality assessment. In: Weaver K,
Kelly C, Eds, Trypsin: Structure, Biosynthesis and Functions. New York: Nova Science Publishers, Inc., 2012; in press.

[31] Rungruangsak K, Utne F. Effect of different acidified wet feeds on protease activities in the digestive tract and on growth rate of rainbow trout (Salmo gairdneri Richardson). Aquaculture 1981; 22 67-79.

[32] Lauff M, Hofer R. Proteolytic enzymes in fish development and the importance of dietary enzymes. Aquaculture 1984; 37: 335-46.

[33] Thongprajukaew K. Feed development using digestive enzyme technology for successive growth in Siamese fighting fish (Betta splendens Regan, 1910). PhD Thesis. Kasetsart University, Department of Zoology, Bangkok, Thailand, 2011.

(C) Rungruangsak-Torrissen et al.; Licensee Bentham Open.

This is an open access article licensed under the terms of the Creative Commons Attribution Non-Commercial License (http://creativecommons.org/licenses/ by-nc/3.0/) which permits unrestricted, non-commercial use, distribution and reproduction in any medium, provided the work is properly cited. 